\title{
COMPULSORY THIRD PARTY INSURANCE: METHODS OF MAKING EXPLICIT ALLOWANCE FOR INFLATION
}

\author{
B. J. BRuton and J. R. Cumpston \\ Australia
}

\section{SUMMARY}

An inflation index is essential when constructing claim payment models from past payment data, and when projecting these results to give estimates of the provisions for outstanding claims and of necessary premiums.

This paper examines the choice of inflation indices for compulsory third party insurance in two Australian states. Two different indices, one based on average weekly earnings per employed male unit and the other based on consumer prices, were tested. The inciex based on average weekly earnings wats considered to be superior in that past claim payment clata, together with this index, gave rensonably stable claim payment models.

Some experiments were made for an actual office to illustrate the effects of different inflation rate assumptions.

\section{INTRODUCTION}

This paper briefly cxamines three problems associated with inflation-

(a) When determining provisions for outstanding claims, and premium rates, how can past claim payments be adjusted to remove the effects of inflation?

(b) What proportion of claim payments, if any, is unaffected by inflation after the accident?

(c) What is the effect of different assumptions in establishing provisions for outstanding claims and premium rates?

\section{General Background}

In Australia, compulsory third party insurance (CTP) covers personal injury received in road accidents, but not damage to vehicles. The amount payable is unlimited, but may be reduced if contributory negligence by the injured person occurred.

In Victoria a large number of insurers shared the market until recently when statutory control of premiums resulted in all but 
two insurers withdrawing from the field. In Western Australia, the Motor Vehicle Insurance Trust has had a statutory monopoly for about twenty-five years.

Data has been supplied by one of the two current Victorian insurers, and by the Motor Vehicle Insurance Trust of W.A. These two insurers are of similar size, each making payments to about 7,500 injured persons per annum. We record our appreciation in being able to publish figures from these two sources.

\section{Insured Casualties}

Data was obtained showing the numbers of vehicles insured during each financial year (period I July to following 30 June), together with claim payments for the corresponding twelve months sub-divided by financial year of accident.

It was considered necessary to convert data on numbers of vehicles insured into data on insured casualties. In both states the introduction of legislation making seat-belt use compulsory has led to a substantial decline in the numbers of persons injured or killed in road accidents per registered vehicle. For this reason it was consiclered that the numbers of insured vehicles provided a poor measure of the underlying exposure to risk.

The increasing use of seat-belts may result in lower claim payments per insured casualty, making insured casualties itself an unreliable measure.

\section{Adjustment for In Flation}

We consider it is most desirable that explicit allowance be made for inflation in determining premium rates and reserves for outstanding claims. Accordingly, past claim payments should be increased by subsequent inflation rates to bring them to current values.

The Australian Bureau of Statistics publishes a number of inflation inclices, of which the most relevant are Average Weekly Earnings per Employed Male Unit (AWE), and Consumer Price Index (CPI).

Payments made in respect of CTP insurance can be classified into a number of categories. Hospital, medical, loss of income and other special damages amount to approximately $20 \%$ of total 
payments. Legal and investigation costs amount to about $20 \%$, and general damages account for the remaining $60 \%$.

Hospital and medical expenses, loss of income payments and legal expenses can be expected to reflect changes in carnings patterns within the community. General damages are awarded by courts (or mutually settled before action) without indication as to the basis of determination; however, these amounts are set against the background of general income levels prevailing at point of payment.

Therefore, on a priori grounds it is considered that AWE is likely to prove a more relevant inflation index than CPI. However, a statistical method of testing the appropriateness of different indices would be useful.

\section{Claim Payments per Insured Casualty}

Table I illustrates claim payments per insured casualty in respect of the Motor Vehicle Insurance Trust of W.A., where past experience has been adjusted using $A W E$ as the inflation index Further tables are shown in Appendix A for Western Australian data using CPI to adjust past experience, and for Victorian data using $A W E$ and $C P I$.

TABLE I

\begin{tabular}{|c|c|c|c|c|c|c|c|c|}
\hline \multirow{2}{*}{$\begin{array}{l}\text { Financial } \\
\text { year of } \\
\text { payment } \\
\text { financial } \\
\text { year of } \\
\text { accident }\end{array}$} & \multicolumn{8}{|c|}{$\begin{array}{l}\text { W.A. claim payments per insured casualty during each of } \\
\text { the following years (claim payments adjusted } \\
\text { to } 30 / 6 / 74 \text { values using AWE index) }\end{array}$} \\
\hline & I $966 / 67$ & $1967 / 68$ & $1968 / 69$ & $1069 / 70$ & $1970 / 71$ & $1971 / 72$ & $1972 / 73$ & $1973 / 7$ \\
\hline & $\$$ & $\$$ & $\$$ & $\$$ & $\$$ & $\$$ & $\$$ & $\$$ \\
\hline o & 60 & $5^{8}$ & 125 & 104 & ror & I I 3 & $124^{*}$ & 124 \\
\hline$I$ & 320 & 395 & 313 & 390 & 366 & 326 & $4 I 4$ & $33 I$ \\
\hline 2 & 469 & $4^{60}$ & 475 & $4^{I} 4$ & 504 & 419 & 438 & $40_{4}$ \\
\hline 3 & 307 & 439 & 388 & 339 & 332 & 308 & 303 & 303 \\
\hline 4 & I 34 & 233 & 218 & I 77 & 236 & 142 & $15^{6}$ & 175 \\
\hline 5 & 75 & 68 & 99 & 86 & 80 & III & 93 & 137 \\
\hline 6 & 50 & 156 & 98 & 193 & $6 \mathrm{I}$ & $3^{6}$ & 52 & 121 \\
\hline 7 & 0 & 69 & 0 & 0 & 0 & 47 & $\sigma_{4}$ & 0 \\
\hline 8 & 0 & 0 & 0 & 0 & 0 & 0 & 81 & 0 \\
\hline Total & $\mathrm{I}, 42 \mathrm{I}$ & $\mathrm{I}, 878$ & 1,716 & 1,709 & 1,680 & 1,502 & 1,725 & 1,595 \\
\hline
\end{tabular}

(* for explanation, see Appendix $\Lambda$ ). 
If the appropriate inflation index has been used, and the conditions affecting payments have been stable, level amounts should appear in each row of the above table.

Accordingly, for each row a straight line was fitted on a least squares basis (ignoring any values marked with asterisks).

This is illustrated in the following graph, where data from the second, third, fifth and sixth rows of Table I, together with fitted lines, has been shown

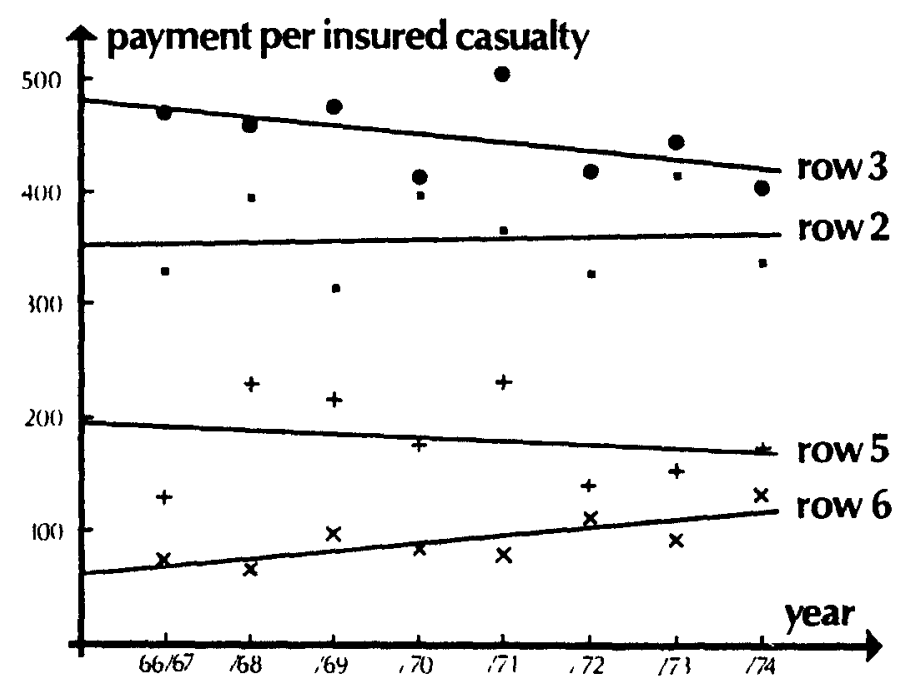

Fig. I

The slope of each of the fitted lines was tested to see if it was significantly different from zero. The following table sets out the slopes of each line together with an asterisk if the slope was significantly different from zero (at the $5 \%$ level).

A two-sided t-test was used, with $(n-2)$ degrees of freedom, where $n$ was the number of observations.

For both states, the fitted lines obtained using AWE had a mixture of positive and negative slopes. By contrast, all but one of the fitted lines obtained using CPI had positive slopes. We consider this provides some indication that AWE is a more suitable inflation index than CPI in adjusting CTP experience. 
TABLE 2

\begin{tabular}{|c|c|c|c|c|}
\hline \multirow{3}{*}{$\begin{array}{l}\text { Financial } \\
\text { year of } \\
\text { payment } \\
\text { financial } \\
\text { ycar of } \\
\text { accident }\end{array}$} & \multicolumn{4}{|c|}{$\begin{array}{l}\text { Slopes of trend lines fitted to claim payments per insured } \\
\text { casualty (claim payments adjusted to } 30 / 6 / 74 \text { values) }\end{array}$} \\
\hline & \multicolumn{2}{|c|}{ W.A. } & \multicolumn{2}{|c|}{ Victoria } \\
\hline & $\begin{array}{l}\text { AWL } \\
\text { index }\end{array}$ & $\begin{array}{l}\text { CI'I } \\
\text { index }\end{array}$ & $\begin{array}{l}\text { A IVE } \\
\text { index }\end{array}$ & $\begin{array}{l}\text { CII } \\
\text { index }\end{array}$ \\
\hline 0 & I I & $12^{*}$ & - I & $-I$ \\
\hline I & 2 & I $5^{*}$ & 4 & I 2 \\
\hline 2 & -8 & J I & -8 & 13 \\
\hline 3 & - II & 3 & -7 & 13 \\
\hline 4 & -3 & 4 & 7 & $18^{*}$ \\
\hline 5 & $7^{*}$ & $9^{*}$ & $29^{*}$ & $32^{*}$ \\
\hline 6 & -4 & $\circ$ & $32^{*}$ & $33^{*}$ \\
\hline
\end{tabular}

Although the significance levels between AWE and CPI were inconclusive, we consider that the lower slopes generally provide further confirmation that AWE: is a more relevant index.

\section{Tests Using Difierent Proportions Unaffected by INFLATION}

The preceding section assumes that all payments arc affected by inflation. However, it is possible that a proportion of payments (for example, hospital and medical expenses) is not affected by inflation after the accident.

TАßЗ.i: 3

\begin{tabular}{|c|c|c|c|c|c|c|}
\hline \multirow{3}{*}{$\begin{array}{l}\text { Financial } \\
\text { year of } \\
\text { payment } \\
\text { financial } \\
\text { year of } \\
\text { accicicnt }\end{array}$} & \multicolumn{6}{|c|}{$\begin{array}{l}\text { Slopes of trend lines fitted to claim payments per insured } \\
\text { casualty (claim payments adjusted to } 3 \% / 6 / 74 \text { values using } \\
\text { AWE index and assuming that proportions }(p) \text { of payments } \\
\text { are not affected by inflation after the accident) }\end{array}$} \\
\hline & \multicolumn{3}{|c|}{ W.A. } & \multicolumn{3}{|c|}{ Victoria } \\
\hline & $p=0.0$ & $p=0.2$ & $p=0.4$ & $p=0.0$ & $p=0.2$ & $p=0.4$ \\
\hline 0 & I I & 11 & I 1 & -1 & $-I$ & -1 \\
\hline I & 2 & 2 & 2 & 4 & 4 & 5 \\
\hline 2 & -8 & -8 & -8 & -8 & -6 & -4 \\
\hline 3 & - II & - I I & -11 & -7 & -4 & -2 \\
\hline 4 & -3 & -3 & -3 & 7 & 10 & $I_{4}$ \\
\hline 5 & $7^{*}$ & $8 *$ & $0^{*}$ & $20 *$ & $33^{*}$ & $37^{*}$ \\
\hline 6 & -4 & -4 & -4 & $32^{*}$ & $3^{6 *}$ & $4^{1 *}$ \\
\hline
\end{tabular}


The following table examines the slope of fitted lines using AWE as an inflation index but assuming $20 \%$ and $40 \%$ of payments are not affected by inflation.

As in the preceding table, the asterisks indicate the statistical significance of the difference from zero of the slopes of the fitted lines.

The above results do not provide any clear support for any particular choice of $p$. Most of the available data, however, camc from a period of low stable inflation rates. Data from a period of unstable inflation rates is necessary before any clear indication as to the true value of $p$ can be obtained.

\section{Weighting Factor}

In order to reduce the effect of year by year fluctuations, it seems desirable that several years' past experience should be combined when making estimates for future experience.

However, it is likely that various changes have occurred in past years which could permanently affect future expericnce, e.g. the growing usc of seat-belts has reduced the severity of road accidents.

Therefore, we consider that data from recent years is likely to be more reliable than old data. This suggests that estimates should be madc using wcighted averages of data from several years, placing more weight on the most recent data.

A method by which this can be achieved is described in Appendix 13. This method involves the use of a weighting factor in the range o to I. Claim payments made " $i$ " years ago are weighted by the factor raised to the power $(n-1)$. A zero weighting factor only considers the most recent year's data, and a weighting factor of $I$ gives a simple mean of the estimates derived from all the available payment data.

\section{Empet ol VARying Assumptions}

To illustrate the effect of varying assumptions on premium rates and provisions for outstanding claims, the following estimates were made for the Motor Vehicle Insurance Trust of W.A. 
I ABLEE 4

P'remutums

\begin{tabular}{|c|c|c|c|c|c|c|}
\hline \multirow{3}{*}{$\begin{array}{l}\text { Weight- } \\
\text { ing } \\
\text { factor }\end{array}$} & \multicolumn{6}{|c|}{ Estumates of necessary earned premums during 1974/75 } \\
\hline & \multicolumn{3}{|c|}{ High future inflation } & \multicolumn{3}{|c|}{ Low future inflation } \\
\hline & $\begin{array}{c}\text { AWJE } \\
\text { index, } \\
P=0 \text { o }\end{array}$ & $\begin{array}{c}\text { AWE } \\
\text { index, } \\
p=0_{4}\end{array}$ & $\begin{array}{c}\text { Cl' } \\
\text { mdes, } \\
p=00\end{array}$ & $\begin{array}{c}\text { AWE } \\
\text { index } \\
p=0 \circ\end{array}$ & $\begin{array}{c}\text { AWE } \\
\text { inclex } \\
p=0.4\end{array}$ & $\begin{array}{c}\text { ClP } \\
\text { inded, } \\
p=00\end{array}$ \\
\hline & $\$ M$ & $\$ M$ & $\$ M$ & $\$ M$ & $\$ M$ & $\$ M$ \\
\hline o o & 197 & 178 & 168 & 130 & 132 & 110 \\
\hline 02 & 199 & 179 & 168 & 131 & 133 & 110 \\
\hline 04 & 200 & 179 & 106 & 132 & I 34 & 109 \\
\hline 06 & 202 & 180 & 163 & I 33 & 134 & 107 \\
\hline o 8 & 203 & I $8 \mathrm{I}$ & 157 & I3 4 & 135 & 103 \\
\hline 1.0 & 20.4 & $18 \mathrm{t}$ & 150 & I3 5 & I3 5 & 99 \\
\hline $\begin{array}{l}\text { Range of } \\
\text { estimates }\end{array}$ & $3 \%$ & $2 \%$ & $11 \%$ & $4 \%$ & $2 \%$ & $10 \%$ \\
\hline & & & $\begin{array}{l}\text { I } \Lambda \mathrm{BLE} \\
\text { tandtng }\end{array}$ & & & \\
\hline
\end{tabular}

Estimates of piovisions necessary for outstanding claims at $30 / 6 / 74$

\begin{tabular}{|c|c|c|c|c|c|c|}
\hline \multirow{2}{*}{$\begin{array}{l}\text { Weight- } \\
\text { ing } \\
\text { factor }\end{array}$} & \multicolumn{3}{|c|}{ High future inflation } & \multicolumn{3}{|c|}{ Low future inflation } \\
\hline & $\begin{array}{l}\text { AWli } \\
\text { index } \\
p=0 \text { o }\end{array}$ & $\begin{array}{c}A W E \\
\text { index } \\
p=0_{4}\end{array}$ & $\begin{array}{c}\text { CPI } \\
\text { inclex, } \\
p=00\end{array}$ & $\begin{array}{l}\text { AWE } \\
\text { Index, } \\
p=00\end{array}$ & $\begin{array}{c}\text { AWE } \\
\text { index, } \\
p=0.4\end{array}$ & $\begin{array}{c}\mathrm{Cl} I \\
\text { index, } \\
p=0 \mathrm{o}\end{array}$ \\
\hline & $\$ M$ & $\$ M$ & SNI & $\$ M$ & $\$ M$ & $\$ M$ \\
\hline 00 & 400 & 367 & 355 & 300 & 298 & 267 \\
\hline 02 & 408 & 373 & 358 & 305 & 302 & 268 \\
\hline 04 & 409 & 373 & 354 & 306 & 302 & 265 \\
\hline 06 & 410 & 373 & 344 & 307 & 30.2 & 258 \\
\hline 08 & $4 \mathrm{II}$ & $37 \mathrm{I}$ & $33 I$ & 309 & 301 & 249 \\
\hline IO & $4 \mathrm{I} \mathrm{I}$ & $37^{\circ}$ & $3+6$ & 310 & $30 \mathrm{I}$ & 238 \\
\hline $\begin{array}{l}\text { Range of } \\
\text { estimates }\end{array}$ & $3 \%$ & $2 \%$ & $12 \%$ & $3 \%$ & $1 \%$ & $12 \%$ \\
\hline
\end{tabular}

Inflation was taken into account on the following bases:

High future inflation. AWE mcreases by $28 \%, 24 \%, 20 \%, 16 \%$ and $13 \%$ for funancial years $1974 / 75$ to I $978 / 79$ and $10 \%$ p.a thereafter.

Low future inflation: AWE increases by $7 \%$ for each future year. 
In all cases CPI increases have been taken as $4 \%$ p.a. less than those for $\mathrm{AWE}$. The above estimates were made assuming:

- investment earnings of $9 \%$ p.a. in future

- claims administration expenses of $I \%$ of the average provision for outstanding claims during the year

- average premium delay of one month

- initial expenses of $x \%$ of premiums

- profit and solvency margins of $12.5 \%$ of premiums.

The above estimates show that when high future inflation is expected, the use of a low index (such as CII) can, as would be expected, lead to underestimation of necessary future premiums and provisions for outstanding claims. In such conditions, the use of a more appropriate index (such as AWE) but too high a value of $p$, can also lead to underestimation. Where a low index is used, the degrec of underestimation increases as the weighting factor increases. This occurs because increasing weight is being placed on payments made many. years ago, which have not properly becn converted to current values.

If low future inflation is cxpected, the use of a low index can also lead to underestimation. The use of a morc suitable index, but too high a value of $p$, may however cause very little error. This is because a high value of $p$ leads to higher claim payments per insured casualty derived from past data, compensating partly or wholly for the underestimation of the future effecis of inflation.

We consider that some indication of the relevance of the inflation inclex can be obtained from the range of results obtained with different weighting methods. The above tables show that the estimates obtained using CPI as an index have a much greater spread than those obtained using AWE. If there is reason to believe that the underlying payment process has been stable for a number of years, then a wide range of estimates resulting from different weighting methods suggests that an inappropriate inflation index has been used. This is only a rough criterion, however, and it would appear unwise to conclude from the above ranges that the use of $\mathrm{AWE}$ with $p=0.4$ is better than the use of AWE with $p=0.0$.

The above tables clearly show the effect of high inflation on this class of insurance. 


\section{Appendix A}

\section{Claim payments per insured casualty}

Table I: See section 5 of text.

Table 6: Western Australia data using CPI to adjust past experience.

Table 7: Victorian data using AWE to adjust past experience. Table 8: Victorian data using CPI to adjust past experience.

TABLE 6

\begin{tabular}{|c|c|c|c|c|c|c|c|c|}
\hline \multirow{2}{*}{$\begin{array}{l}\text { IFinancial } \\
\text { year of } \\
\text { payment } \\
\text { financial - } \\
\text { year of } \\
\text { accident }\end{array}$} & \multicolumn{8}{|c|}{$\begin{array}{l}\text { W.A. clain payments per insured casualty during each of } \\
\text { the following ycars (claim payments adjusted } \\
\text { to } 30 / 6 / 74 \text { values using CPI inclex) }\end{array}$} \\
\hline & $1960 / 67$ & I $967 / 68$ & $1968 / 69$ & $1969 / 70$ & $1970 / 71$ & $1971 / 72$ & $1972 / 73$ & $1973 / 74$ \\
\hline & $\$$ & $\$$ & $\$$ & $\$$ & $\$$ & $\$$ & $\$$ & $\$$ \\
\hline 0 & $4 \mathrm{I}$ & 42 & 95 & 83 & 87 & 102 & I I $2^{*}$ & $118^{*}$ \\
\hline I & 224 & 285 & 237 & 318 & 315 & 293 & 373 & 315 \\
\hline 2 & 323 & 332 & 359 & 332 & 435 & 377 & 394 & $3^{8} 4$ \\
\hline 3 & 211 & 317 & 294 & 272 & 286 & 277 & 273 & 288 \\
\hline 4 & 92 & 168 & 165 & 142 & 203 & 128 & $I_{4} \mathrm{I}$ & 166 \\
\hline 5 & $5^{2}$ & 4) & 75 & 6o & $6 y$ & 100 & $8_{3}$ & 130 \\
\hline 6 & 34 & 113 & 74 & 155 & 52 & 33 & 47 & I 15 \\
\hline 7 & 0 & $5^{\circ}$ & 0 & 0 & 0 & 42 & $5^{8}$ & o \\
\hline 8 & o & 0 & o & 0 & 0 & o & 73 & 0 \\
\hline Total & 977 & $I, 356$ & 1,299 & $1,37^{1}$ & I, 447 & $I, 352$ & 1,554 & $1,5 \mathrm{I} 6$ \\
\hline
\end{tabular}

TABLF 7

\begin{tabular}{|c|c|c|c|c|c|c|c|c|c|}
\hline \multirow{2}{*}{$\begin{array}{l}\text { Financial } \\
\text { year of } \\
\text { payment } \\
\text { financial } \\
\text { year of } \\
\text { accident }\end{array}$} & \multicolumn{9}{|c|}{$\begin{array}{c}\text { Victorian claim payments per insured casualty cluring each of } \\
\text { the following years (claim payments adjusted } \\
\text { to } 30 / 6 / 74 \text { values using } A W E \text { index) }\end{array}$} \\
\hline & $\begin{array}{c}1965 / \\
66\end{array}$ & $\begin{array}{c}1966 / \\
67\end{array}$ & $\begin{array}{c}19671 \\
68\end{array}$ & $\begin{array}{c}1968 / \\
69\end{array}$ & $\begin{array}{c}1969 / \\
70\end{array}$ & $\begin{array}{c}1970 / \\
7^{1}\end{array}$ & $\begin{array}{l}x 971 / \\
\cdot 72\end{array}$ & $\begin{array}{c}19721 \\
73\end{array}$ & $\begin{array}{c}1973 \\
74\end{array}$ \\
\hline & $\$$ & $\$$ & $\$$ & $\$$ & $\$$ & $\$$ & $\$$ & $\$$ & $\$$ \\
\hline 0 & 24 & 19 & 14 & 21 & I9 & I 6 & $3^{6 *}$ & $53^{*}$ & $50^{\prime \prime}$ \\
\hline$t$ & & 260 & 259 & 245 & 273 & 165 & 247 & 264 & 314 \\
\hline 2 & & & $5^{8} 3$ & Gro & 603 & 529 & 494 & $55^{\circ}$ & 588 \\
\hline 3 & & & & $55 \mathrm{I}$ & 609 & 537 & $54 \mathrm{I}$ & 510 & $5^{6} \sigma_{3}$ \\
\hline 4 & & & & & 380 & 394 & 349 & $4 I 4$ & 407 \\
\hline 5 & & & & & & 196 & 204 & 246 & 278 \\
\hline 6 & & & & & & & 97 & 127 & 161 \\
\hline $\begin{array}{l}7 \\
8\end{array}$ & & & & & & & & 57 & $\begin{array}{l}83 \\
4 I\end{array}$ \\
\hline
\end{tabular}


TABLE 8

\begin{tabular}{|c|c|c|c|c|c|c|c|c|c|}
\hline \multirow{2}{*}{$\begin{array}{l}\text { linancial } \\
\text { year of } \\
\text { paymcnt } \\
\text { financial } \\
\text { year of } \\
\text { accident }\end{array}$} & \multicolumn{9}{|c|}{$\begin{array}{c}\text { Victorian claim payments per insured casualty cluring each of } \\
\text { the following years (claim payments adjusted } \\
\text { to } 30 / 6 / 74 \text { values using CPI index) }\end{array}$} \\
\hline & $\begin{array}{c}1965 / \\
60\end{array}$ & $\begin{array}{c}5960 / \\
67\end{array}$ & $\begin{array}{c}19671 \\
68\end{array}$ & $\begin{array}{c}1968 / \\
69\end{array}$ & $\begin{array}{c}1960 / \\
70\end{array}$ & $\begin{array}{c}1970 / \\
71\end{array}$ & $\begin{array}{c}1971 / \\
72\end{array}$ & $\begin{array}{c}19721 \\
73\end{array}$ & $\begin{array}{c}1973 / \\
74\end{array}$ \\
\hline & $\$$ & $\$$ & $\$$ & $\$$ & $\$$ & $\$$ & $\$$ & $\$$ & $\$$ \\
\hline 0 & I7 & 14 & 10 & I6 & I6 & 14 & $33^{*}$ & $49^{*}$ & $4^{8 *}$ \\
\hline I & & 193 & 196 & 193 & 228 & 146 & 224 & 247 & 300 \\
\hline 2 & & & $44^{I}$ & $4^{80}$ & 503 & $4^{67}$ & 449 & 514 & 561 \\
\hline 3 & & & & 434 & 507 & 474 & $49^{\mathrm{T}}$ & 477 & 5.37 \\
\hline 4 & & & & & 317 & $34^{8}$ & 316 & $3^{88}$ & 388 \\
\hline 5 & & & & & & 173 & 185 & 230 & 265 \\
\hline 6 & & & & & & & 88 & II9 & I 53 \\
\hline 7 & & & & & & & & 53 & 80 \\
\hline 8 & & & & & & & & & 39 \\
\hline
\end{tabular}

Values marked with an asterisk are suspect, as they depend considerably on the accuracy of adjustments made in order to remove the effects of no-fault payment schemes. All the Victorian values are approximate, as they have been derived from records sub-divided by year of reporting, not ycar of accident.

\section{Appendix 13}

\section{Estimation methods}

Let $m(k)$ be the claim payments (in current values) per unit of risk, paid in the $(k-I)$ th year after the year of accident, which is to be estimated

$c(j)$ be the conversion factor used to convert claim payments during the $j$ 'th most recent payment year to current values (assuming that $100 \%$ of all payments are directly linked to the inflation index)

$e(j)$ be the exposure to risk in the $j$ 'th most recent accident year

$p$ be the proportion of claim payments not affected by inflation after the accident

$P(j, k)$ be the claim payments made in the $j$ th most recent payment year as a result of accidents in the $(k-I)$ th.ycar prior to the payment ycar 
$n$ be the number of payment years for which data is available $M(j, k)$ be the estimate of $m(k)$ derived from $P(j, k)$

$w$ be the weighting factor used when combining values of $M(j, k)$ in order to make an estimate of $m(k)$

$g(i)$ be the increase in the inflation index forecast during the $i$ 'th future year

and $F(i, j)$ be the claim payments in the $i$ th future year rosulting from the $j$ 'th most recent accident ycar.

The estimation methods used in this paper were:

$$
\begin{aligned}
M(j, k) & =\frac{P(j, k)}{e(j+k-\mathrm{I})}\left[\frac{c(j)}{\left.(\mathrm{I}-p)+p \frac{c(j)}{c(j)+k-\mathrm{I})}\right]}\right. \\
m(k) & =\frac{\sum_{i=1}^{n} w^{j-1} M(j, k)}{\sum_{j=1}^{n} w^{j-1}} \\
F(i, j) & =e(j) \frac{m(i+j)}{c(j)}\left[p+(\mathrm{I}-p) c(j) \prod_{k=1}^{i-1}(\mathrm{I}+g(k))\left(\mathrm{I}+\frac{g(i)}{2}\right)\right]
\end{aligned}
$$

